ARCHIV FÜR INDISCHE PHILOSOPHIE 



\section{Claus Oetke}

\section{Prasannapadā 19,3-7 and Its Context}

I

In an article which has been published recently in the Wiener Zeitschrift für die Kunde Südasiens Anne MacDonald presented some results of her studies on Candrakīrti's Prasannapadā that exploit a number of manuscripts for the first time for a critical edition of the text and which appear to me to belong to a minority in present Sanskrit studies that promise to yield substantial progress in some area. ${ }^{1}$ In order to highlight the relevance of detailed and critical investigations of this work I will examine a short textual passage together with its pertinent context. More specifically, I will recommend an interpretation of the segment that differs from the one which has been adopted in the article and attempt to show that the proposal helps to make more fruitful the text-critical considerations which the author of the mentioned paper has made in connexion with the textual passage. On this background some more general methodological principles will be propagated. However, the question of their validity does not essentially rely on the correctness or preferability of the interpretation I offer.

The textual passage which is the object of the present investigation occurs on p. 19,3-7 of L. de la Vallée Poussin's edition of the Prasannapadā. According to that edition - we refer to it in the following by "LVP" - it reads as follows:

tasmād eṣa tāvan nyāyah. yat parenaiva sväbhyupagatapratijñātārthasādhanam upādeyam. na cāyam param prati [hetuh]. hetudṛ̦țāntāsambha-

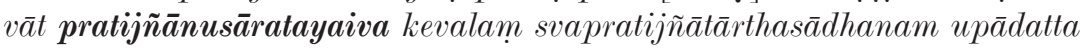
iti nirupapattikapakșābhyupagamāt svātmānam evāyam kevalam visaṃvādayan na śaknoti pareșām niścayam ādhātum iti. idam evāsya spaștatarad̄usanam yaduta svapratijñātārthasādhanāsāmarthyam iti kim atrā-

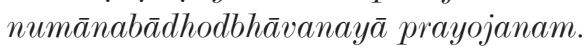

1 Anne MacDonald, The Prasannapadā: More Manuscripts from Nepal. WZKS 44 (2000) 165-181. 
On the basis of the new manuscript-material which Anne MacDonald takes into consideration, she proposes a reading which differs at some points:

tasmād esa tāvan nyāyo yat parenaiva svābhyupagatapratijñātārthasādhanam upādeyam. sa cāyam param prati hetudṛștāntāsaṃbhavāt svapratijñ̄̄mātrasāratayaiva kevalam svapratijñātārthasādhanam upādatta iti nirupapattikapakșābhyupagamāt svātmānam evāyam kevalam visaṃvādayan na śaknoti pareșām niścayam ādhātum iti. idam evāsya spaștataram

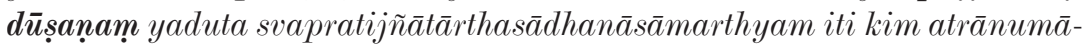
nabādhodbhāvanayā prayojanam.

The deviances between both readings have been marked by using bold letters. As far as the analysis of the content is concerned, it appears that only one difference is relevant, namely that between

na cāyam param prati [hetuḥ]. hetudṛ̦tāntāambạbavāt pratijāānusāratayaiva

and

sa cāyam param prati hetudṛștāntāsambhavāt svapratijñ̄āmātrasāratayaiva.

My thesis is that the emendations should be accepted except for one detail and I propose the following reading:

sa cāyam param prati hetudṛ̣tāntāsambhavāt pratijñāmātrasāratayaiva.

However, I differ over the interpretation of the cited passage. According to MacDonald the segment could be translated as follows (MacDonald, op. cit., p. 179):

Therefore, this, first, is the regular procedure [for proof for another]: only the opponent has to employ a proof of the matter maintained and proposed by himself. But this very one (= the Sānkhya), due to the impossibility of reasons and examples against [his] opponent, employs a proof of the matter proposed by himself only in such a way that the main constituent is merely [his] own thesis; thus, since he maintains a proposition lacking in logical reasoning he, disagreeing with no one but himself, is not able to instill certainty in [his] opponents. Just this is the [Mādhyamika's] very clear criticism of him, namely, [he] is incapable of proving the matter proposed by himself; under these circumstances, what is the use of bringing out the sublation [of his thesis] by an inference?

In order to assess the pros and cons it is indispensable to consider the context in which the cited textual passage occurs, especially the preceding context. It seems that the foregoing passage beginning with p. 14,1 
according to de La Vallée Poussin's edition contains everything which is relevant for an assessment. It reads as follows:

$\bar{a} c \bar{a} r y a b u d d h a p \bar{a} l i t a s$ tv $\bar{a} h a$. na svata utpadyante bhāvāh, tadutpādavaiyarthyāt. atiprasaingadoșāc ca. na hi svātmanā vidyamānānām padārthānām punarutpāde prayojanam asti. atha sann api jāyeta, na kadācin na jāyeta, iti.

atraike dūṣanam āhuh, tad ayuktam, hetudrștāntānabhidhānāt, parokta-

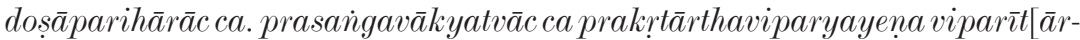

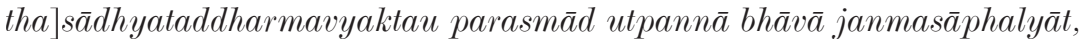
janmanirodhāc ceti kṛtāntavirodhah syāt.

sarvam etad dūṣanam ayujyamānam vayam paśyāmah. katham kṛtvā, tatra yat tāvad uktam hetudṛ̦țāntānabhidhānād iti tad ayuktam. kim kāananam, yasmāt parah svata utpattim abhyupagacchan vidyamānasya punarutpāde prayojanam prcchyate. svata iti hetutvena tad eva cotpadyata iti, na ca vidyamānasya punarutpattau prayojanam paśyāmah̆, anavasthām ca paśyāmah. na ca tvayotpannasya punarutpāda isyate 'na $\lfloor v a s t h \bar{a}\rfloor$ cāpy anișteti, tasmān nirupapattika eva tvadvādah svābhyupagamaviruddhaś ceti. kim [tanmātrena] codite paro nābhyupaiti yato hetudrștāntopādānasāphalyam syāt. atha svābhyupagamavirodhacodanayāpi paro na nivartate, tadāpi nirlajjatayā hetudr ștāntābhyām api naiva nivarteta. na conmattakena sahāsmākam vivāda iti.

tasmāt priyānumānatām evātmana ācāryah prakatayati, asthāne 'py anumānam praveśayan. na ca mādhyamikasya svatah svatantram anumānam kartum yuktam pakșāntarābhyupagamābhāvāt. tathoktam āryadevena ...

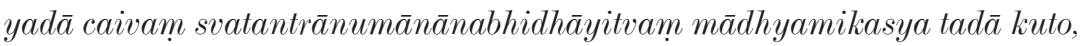

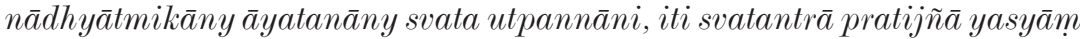
sāmkhyāh pratyavasthāsyante, ko 'yam pratijñarthah, kim kāryātmakāt svata uta kāranātmakād iti. kim cātah, kāryātmakāc cet siddhasādhanam,

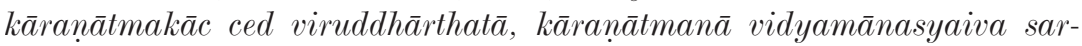

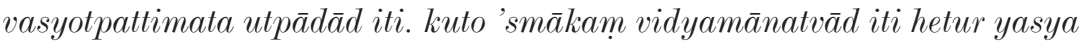
[siddhasādhanam $\rfloor$ viruddhārthatā $\lfloor v \bar{a}\rfloor$ syāt, yasya siddhasādhanasya yasyāś ca viruddhārthatāyāh parihārārtham yatnam karișāmah. tasmāt paroktadoș $\lfloor\bar{a}\rfloor$ prasaingād eva tatparih $\bar{a} r a \bar{a} c \bar{a} r y a b u d d h a p \overline{a l i t e n a}$ [na $\rfloor$ varnanìyah.

athāpi syāt, mādhyamikānām pakṣahetudṛ̦tāntānām asiddheh svatantrānumānānabhidhāyitvāt svata utpattipratiședhapratijñātarthasādhanam mā bhūd ubhayasiddhena vānumānena parapratijñ̄anirākaranam, parapratijñāyās tu svata evānumānavirodhacodanayā svata eva pakṣahetudṛstāantāpakșālarahitaih ${ }^{2}$ pakșādibhir bhavitavyam. tataś ca tadanabhidhānāt taddoșāparihārāc ca sa eva doṣa iti.

2 Cf. MacDonald, op. cit., p. 172 with n. 24; LVP: -drsțāntadoșarahitaih. 
ucyate, naitad evam. kim kāraṇam. yasmād yo hi yam artham pratijānīte, tena svaniścayavad anyeșām niśsayotpādanecchayā yayopapattyāsāv artho 'dhigatah saivopapattih parasmāy upadeștavyā.

Assuming that this text is sufficiently reliable at least for the relevant purpose of reconstructing the argumentative situation, one can describe the train of thoughts of that passage as follows:

1) The [Mādhyamika] master Buddhapālita has said [in order to refute the thesis that things originate from themselves]: "The things do not originate from themselves, because their origination would be meaningless and because this would imply an excess of [undesired] consequences. For there is no use for the re-origination of objects that are [already] existing in their own essence (i.e. which exist as that what they are). Or [one assumes that something] originates although it is [already] existing. [In that case] it should never not originate."

2) Against this some (i.e. in particular Bhāvaviveka) raise the following objection: This is improper, because an inferential reason (hetu) and an example (drsțānta) have not been presented [in Buddhapālita's proof] and because the faults [of that argumentation] which have been pointed out by the opponent (i.e. the defender of the Sāmkhya-position) have not been refuted. Moreover, since, on account of the fact that [it] (i.e. Buddhapālita's argument) is a statement of [undesired] consequences [which intrinsically result from the opponent's own thesis], a probandum as well as properties of that (i.e. the substratum) $)^{3}$ emerge which are opposite by being opposed to the pertinent objects/meanings - i.e. opposed relative to the (meaning of the) predicate which is in the scope of the negation in Buddhapālita's thesis as well as to (the meaning of) the reasons offered by Buddhapālita - [it must hold true that] the things originate from something different because [in this case] origination [would] possess a purpose and origination [would] come to an end

3 Possibly, the compound refers to two different uses of the expression $s \bar{a} d h y a$, namely to the property which is to be inferred on the one hand, and the substratum of the inference, i.e. the pertinent property-bearer, on the other, such that the employment of tad-in -taddharma-relates to the latter use in particular. This means that sadhya and taddharma might refer to the property to be proven and the proving property/properties respectively. Fortunately, however, the reconstruction of the train of thought is apparently not affected by the problems and uncertainties of interpretations concerning the phrase prasangavākyatvāc ca prakrtārtha-

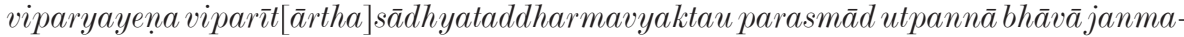
sāphalyāt, janmanirodhāc ceti krtāntavirodhah syāt. 
(i.e. not an infinite series of originations result as a consequence); therefore a contradiction with the accepted tenet (namely Buddhapālita's own view that things do not originate from something different either) would result.

3) In "our" (i.e. in Candrakīrti's) opinion this entire reproach is unjustified. [If one asks] "why?", [the following is to be said:] The remark to the effect that an inferential reason and an example have not been stated is inappropriate, because the (Sāmkhya-)opponent who assumes an origination of something from itself is asked about the use [which might be fulfilled] if a re-origination of something [already] existing [occurred], since [the expression] "from itself" [means that it exists] as a cause and [on the other hand] that very thing originates. But one cannot discern any use in something's originating again and [simultaneously] one discerns an infinite regress. But the proponent of the Sāmkhya-view (literally: "you") does not like to assume a re-origination of something which has [already] originated, and an infinite regress is not desired either. Therefore the doctrine of the Sāmkhya is without [any reasonable] basis and militates against his own assumptions. If only so much is brought forward [against him], what is there which the opponent does not [yet] admit, so that the mention of an indicating reason and an example might fulfil some purpose? Or is it so that the opponent is not brought to abstain from his views even by pointing out to him a contradiction concerning that which he himself accepts? Even then [it holds good that] because of his shamelessness not even reasons and examples would make him give up his view. But we (i.e. the Mādhyamika) do not engage in a discussion with somebody who is crazy. Therefore the teacher (Bhāvaviveka) manifests nothing but his own [excessive] predilection of inference (anumāna), since he brings inference into play even at a place which is not proper [for it].

4) On the other hand, it is not proper for a Mādhyamika to make an independent inference of his own accord, because he does not assume any particular theses. (Citations from a text of Āryadeva and the Vigrahavyāvartanī are presented in order to support this assertion.)

5) If thus the Mādhyamika does not pronounce an independent inference, where should there be an independent assertion [like] "The internal Ayatanas have not originated from themselves" so that the Sāmkhya-proponents could object to it [by saying:] "What is the meaning of the assertion here? Is it 'from themselves in the form of an effect' or 'in the form of a cause' (i.e. is the meaning of the assertion that the 
inner Āyatanas do not originate from themselves in the form of an effect or that they do not originate in the form of a cause)? [If one asks] what [should follow] from this [alternative], [then we reply:] If [the assertion is that the inner Âyatanas do not originate] from [themselves] in the form of an effect (i.e. as effects), [then the assertion serves only as] a means of establishing something which is [already] established; if [on the other hand the assertion is that they do not originate] from [themselves] in the form of a cause (i.e. as causes), [then the assertion] has a contradictory import because everything that possesses origination originates only inasmuch as it exists in the form of a cause." [Moreover,] where do we have an inferential mark [like] "because it is existing" which [might] possess [the defect of] proving something which is [already] established or having a contradictory import, so that we should make an effort to remove [the defect] that it establishes something which is established or that it possesses a contradictory import? Since therefore the defects which are mentioned by the opponent simply do not apply there is no need that the master Buddhapāita explicitly rejects [them].

6) It might be said that since for the Mădhyamikas theses (pakṣa), logical indicators and examples are not established [as existing] and since they therefore are not ones who utter independent inferences there might not exist [in this context of discussion] a means of establishing an asserted proposition [which is] a denial of origination from itself $f^{4}$ or the exclusion of an opponent's assertion by some means of inferring which is established for both parties; nevertheless, since [the Mādhyamika] reproves [the opponent] of [advocating a tenet which is beset by] a contradiction on account of an inference of his own accord, he must have theses and other [members of an inference] of his own accord which are free from defects [pertaining to] thesis, indicator and example. Therefore the very deficiency [which has been pointed out before remains] because those [members of an inference] have not been mentioned and their [possible] defects have not been removed [by Buddhapālita].

7) Against this the following is said: This is not so. [If one asks] Why? [the reply is:] Because the very same person who asserts some proposition, must, because of his desire to instill an ascertainment in other people in the same manner as [he has instilled] an ascertainment in

4 Or: "... he might not have a means of ... of his own". 
himself, point out to some other person precisely that justification by which he [himself] has recognized the proposition [as true].

The train of thought can be summarized as follows: 1) Buddhapālita's refutation of the proposition of self-origination is presented. 2) An objection is brought forward to the effect that a) Buddhapālita's refutation lacks certain members which are required in a canonical proof, $b$ ) the refutation lacks an explicit rejection of the reproach that it is beset by other non-formal defects, c) involves an incompatibility with Buddhapālita's own view according to which things do not originate from other things. 3) The contention involved in a) that Buddhapālita's refutation must exhibit all members of a canonical proof is rejected on account of the consideration that the negation of the counter-thesis is derived merely by reference to facts which are presupposed in the counter-thesis itself. 4) It is pointed out that for a Mādhyamika at least it is not merely unnecessary but even improper to present a canonical proof because his own doctrine does not allow him to advocate a special thesis [in which the existence of some particular entity is presupposed]. Since the objector acknowledges himself the basic Madhyamaka-tenets his demand is therefore improper. 5) On account of 4) there is no reason why a Mădhyamika should be obliged to remove potential defects of a thesis and the same applies to inferential indicators. 6) A new objection is put forward. It is now acknowledged that since certain members of a canonical proof involve certain (existential) presuppositions which cannot be recognized as true by a Mādhyamika, it is appropriate to grant that in the pertinent context of discussion an independent proof for the denial of some proposition or an inference that refutes some counter-thesis and which is valid according to the standards of both parties involved in the discussion must not be presented. But since even in the present context it is claimed by the Mādhyamika that the counter-thesis is contradicted by some inference he is obliged to present some thesis, inferential indicator and example which are demonstrably devoid of any flaws. ${ }^{5}$ 7) Candrakinti counters this objection by claiming that somebody who makes some assertion must justify it to other per-

5 I prefer to connect svatah in the phrase svata evānumānavirodhacodanay $\bar{a}$ syntactically with -codanaya and not with anumāna-. The meaning is that the Mādhyamika himself "categorically" - and not merely hypothetically or under some premise - claims that the opponent's tenet is incompatible with the result of an inference. 
sons by the same justifying grounds by which he himself has convinced himself of the truth of what is asserted, if he wants to convince others.

In order to be in a better position for an assessment of the argumentative situation as well as the discussion which will follow we should make clear what the objector's demand that is stated in 6) amounts to: It means that the Mãdhyamika should present a proof of the form "A does not originate from itself, because A possesses the quality $\mathrm{H}$, like B". Since it is explicitly acknowledged that a Mādhyamika cannot accept indicators and examples in the final analysis, the objector's proposal creates a queer situation: The Mādhyamika is invited to argue on the basis of premises which he himself does not consider as true. It is as if he should say: "A does not originate from itself, because A is F like $\mathrm{B}$, but according to my own opinion it is not true that $\mathrm{A}$ is $\mathrm{F}$ and in the final analysis there is no $\mathrm{B}$ - and $a$ fortiori there is no $\mathrm{B}$ which is F."

\section{III}

It has been mentioned in the preceding paragraph that according to MacDonald the reading

na cāyam param prati [hetuh]. hetud!̣̦țāntāsambhavāt pratijñ̄̄nusāratayaiva

should be emended to the reading

sa cāyam param prati hetudṛ̦tāntāsambhavāt svapratijñāmātrasāratayaiva.

The most important change pertains to the substitution of $n a$ by $s a$. Let us simply accept the contention that this emendation can be justified on account of the circumstance that the aksaras sa and na are easily confused (cf. MacDonald, op. cit., p. 178). But some of the remarks which refer to the difficulties of hypothesizing the alternative reading should be examined a bit more closely. It is said that

[if the reading na cāyam were accepted] ayam cannot refer to the Sānkhya, for, depending on the scope allocated to the initial na (i.e. its limit being either upādatte or $\bar{a} d h \bar{a} t u m$ ), the sentence would be at the least self-contradictory, or a most unexpected and unlikely defense of the opponent. 
And further (cf. p. 177):

But should it be assumed that the subject is the Mādhyamika, we are met with an untimely and strange defense of the Mādhyamika's procedure of proof, would have to accept that asya of the next sentence does not refer back to ayam of the previous, and are confronted overall with a logically unsatisfying sequence of statements.

Although it is by no means our intention to claim that this is the correct interpretation, it deserves to be noted that the statements cited above do not mention another possibility: Let us assume that the scope of the negation reaches either till upādatta iti or even till niścayam ādhātum iti inclusive and that ayam in na cāyam param prati has no direct reference either to the Sānkhya or a Mādhyamaka, but should be taken as co-referential with parena in the preceding sentence. The idea is that the correct norm is that described by the clause yat parenaiva svabhyupagatapratijñātārthasādhanam upādeyam and that the procedure which is depicted in the following does not comply with it. In the present context it is not appropriate to say that this proposal seems prima facie unnatural because it entails that param and param prati are not co-referential with parena in the preceding sentence but that param rather refers to the opponent or interlocutor of the subject to which parena relates. For first it is illegitimate to rule out a possibility merely because one's own intuition bestows higher prima facie plausibility to other alternatives and secondly, as indicated above, we do not claim that this reading and interpretation are correct. The significance of that alternative stems from the fact that it is confronted with similar difficulties as the solution which has been proposed by MacDonald.

There is a structural similarity between both proposals. According to MacDonald the passage beginning with p. 19,3 first says what the "regular procedure" for a proof is and adds to this a remark to the effect that the Sāmkhya-proponent does not comply with this maxim; according to the envisaged possibility first the valid norm for proofs is stated (as in MacDonald's interpretation) and then it is specified what does not comply with that norm. The difference is merely that according to the latter alternative something is said in a less specific form than according to the former interpretation, since the statement exhibits the following form: "The norm (nyāya) for a proof is $\mathrm{P}$, but not that Q." The point of making a statement of this kind would have to be seen in the fact that it conversationally conveys that if somebody acts according to the way described in "Q" he would not comply with the norm that should be regarded as valid for (public) proofs. If the sequence of 
expressions which follows after na ca embodied a truthful description of what the Samknya-proponent is in fact doing, this should be no surprise because the alternative that is envisaged by us allows for the possibility to assign to the employment of those expressions the function to point out that the Sāmkhya-procedure does not comply with the norm for a public proof. The difference is merely that according to MacDonald's reading and interpretation the defect would be related to the Sāmkhya-proponent in a more direct manner than according to the rival reading and interpretation.

But should we accept at all that the passage that begins with either na $c a$ or $s a$ ca represents any reference to the Sāmkhya? There are certain facts which could induce one to adopt this view, but one should resist the temptation. To be sure, MacDonald's interpretation seems to harmonize nicely with the following observations: a) In the passage of LVP p. 19,3ff. the expression nirupapattikapakșäbhyupagamāt occurs and in LVP p. 15,7 (see section 3) above) we find tasmān nirupapattika eva tvadvādah, and in the latter passage the reference to the Samkhya cannot be doubted. b) In LVP p. 15,7 svābhyupagamaviruddha- and in LVP p. 15,9 sväbhyupagamavirodha- occur in a context in which the reference to the Sāmkhya-position is clear and in LVP p. 19,5 we find svātmānam evāyam kevalam visamvādayan, so that one could think that the disagreement with oneself mentioned in the latter passage relates to the same as the contradiction with one's own assumption in the former passage(s). Nevertheless, if one looks closer at the matter it turns out that those parallels are probably superficial and the similarities lose significance.

Let us grant for the time being that the expression nirupapattikapakșābhyupagamāt svātmānam evāyam kevalam visamveādayan, taken by itself, could properly describe a relevant procedure of a supporter of the Sāmkhya-doctrine. But what should we say about the preceding

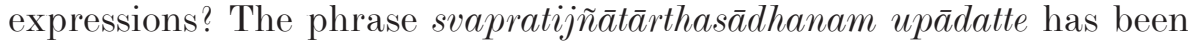
rendered by MacDonald as "employs a proof of the matter proposed by himself" and since this should relate to the advocate of the Sāmkhyatenet, the question arises where it has ever been said or at least insinuated in the preceding textual passage that any Sāmkhya-proponent has offered a proof of his thesis. To be sure, actual or potential proofs have been made thematic in the preceding context, but all of them relate to actual or potential refutations of the proposition that things originate from themselves and can certainly not be regarded as arguments for any proposition supported by the Sāmkhya. 
Moreover, the expression param prati hetudṛțtāntāsambhavāt svapratijñ̄amātrasāratayaiva means according to MacDonald "due to the impossibility of reasons and examples against [his] opponent ... only in such a way that the main constituent is merely [his] own thesis" which engenders the problem on which basis it could be said at least with respect to any potential proof of the Sāmkhya-tenet against any opponent, including a Mādhyamika, that he offers it in a way that the main constituent is merely his own thesis and that this is due to the circumstance that reasons and examples against his opponent are impossible. To be sure, one might be tempted to relate this remark to the fact that if a Sāmkhya-proponent would prove his own thesis in a canonical way against a Mādhyamika, he could not adduce indicators and examples which are recognized (as existing on the level of final analysis) by his opponent and would accordingly possess no means to convince his actual opponent by a canonical proof on the basis of some indicator as well as an inseparable connection between indicator and property to be proven which is exemplified by some example such that both indicator and example(s) are acknowledged as existent by both parties of the controversy.

But first this poses the problem what the precise import of svapratijñ $\bar{a}$ mātrasāratayaiva = "in such a way that the main constituent is merely [his] own thesis" should be. Should it perhaps refer to the fact that the Sāmkhya-proponent cannot rely on undisputed indicators and examples? But why should this engender a situation in which "the main constituent is merely his own thesis"? After all, the Mādhyamika calls not merely indicators and examples into question but also, and in the first place, the Sāmkhya-thesis that things originate from themselves. Should we assume that the expression is a clumsy means of referring to the fact that the Sāmkhya-proponent has no means to base his tenet on means of proof which are recognized as valid by both parties if he discusses with a Mādhyamika, given that he, the Sāṃkhya-proponent, intends to employ a canonical anumana, so that his own thesis stands against the thesis of his opponent without any common ground which could make a decision between the alternatives possible? But, apart from the fact that MacDonald does not unmistakably indicate that the pertinent expression should be related to this point and omits to say what the expression svapratijñāmātrasāratayaiva should mean in clear, the question arises as to why the author of the text should have expressed his thought in such an obscure manner although there would be alternative ways to make the point plain. 
Moreover, it becomes now mysterious why the Sāṃkha-proponent should be described as someone who "disagrees with no one but himself". After all, in the envisaged situation the Sāṃkhya-proponent is only bereft of some possibility to establish a tenet against some particular opponent, but not on account of some inherent property of his own proof but merely because the opponent just refuses to accept certain premises.

At any rate, the possible support for the interpretation on account of the similarity of some expression with LVP p. 15,7-8 would become invalid because there is no doubt that the expression sväbhyupagamaviruddhaś (ceti) in the parallel passage does not relate to the circumstance that the advocate of the Sāmkhya-tenet cannot prove his thesis in a canonical manner because his opponent does not acknowledge indicators and examples.

Moreover, what is the argumentative function of pointing out that the supporter of the Sāmkhya-doctrine of self-origination cannot offer a canonical proof against a Mādhyamika? If such a proof should be impossible, it is natural to draw the consequence that this is not the correct type of proof for the pertinent case and that the notion of a canonical anumāna is too narrow in order to encompass all means of proof which are in fact needed. After all, the Prāsangika-school and Candrakīrti himself appear to advocate the view that canonical anumanas are not suited to establish the principal tenets of Madhyamaka. To be sure, in principle it is conceivable that Candrakīrti points out that he himself is not the only one who needs to transgress the narrow boundaries of canonical anumānas and it could be relevant to show that the Sāmkhya is in a similar position. But again one must say that if this were the relevant point at the pertinent textual passage, one should expect an entirely different wording of the textual passage. All these difficulties are aggravated by the fact that the preceding sentence refers to the "principle" that a proponent, if he acts as an opponent in some debate, must employ a means of proof of his tenet which he himself regards as valid. If the fact were relevant that the Sāmkhya cannot employ indicators and examples which are acknowledged by his Mādhyamika-opponent one might expect that the maxim of exploiting means of proving that are accepted also by the opponent is highlighted, but it appears totally mysterious under these premises why the preceding remarks in our textual passage emphasize that everybody who proves something against somebody else must employ the same evidence which he himself has used in order to accept the pertinent proposition as true. 
The initial remarks of Candrakīrti's reply which is represented by ucyate, naitad evam. kim kāranam. yasmād yo hi yam artham pratijānūte, tena svaniścayavad anyeșām niścayotpādanecchayā yayopapattyāsāv artho 'dhigatah saivopapattih parasmāy upadeștavyā does not at all harmonize with the supposition that in the subsequent passage the fact that a Sāmkhya-proponent cannot convince a Mādhyamika-opponent by a canonical proof is made thematic, except one makes the following supposition: The initial passage which formulates the requirement that a proponent must in a proof refer to the basis by which he himself has recognized the probandum as true together with the maxim that an interlocutor in a debate has to employ a means of proof of a tenet that is accepted by himself, serves to point out that compliance with the standard norm of proofs would not be sufficient in a situation in which a Sāmkhya-proponent argues against a Mādhyamika. The schema of the thought would be like this: "The norm for (canonical) proofs against opponents is P. But this one, i.e. the Sāmkhya-proponent, cannot convince Mādhyamika-opponents in this manner, because of Q.'

However, difficulties which had been pointed out before remain: It is hard to see why the Sāmkhya-proponent should become inconsistent with himself on any other ground than the fact that his thesis presupposes or implies propositions which entail its negation - as has been pointed out by Buddhapālita but which has nothing to do with the circumstance that the Sāmkhya-proponent intends to prove something - and it appears difficult to find any plausible elucidation of the phrase hetudrṣtāntāsambhavāt (sva)pratijñāmātrasāratayaiva kevalam svapratijñātarthasādhanam upādatta (iti). Moreover, the global argumentative function of the entire passage is unclear under those premises. What does Candrakīrti want to tell us by mentioning the circumstance that the Sāmkhya-proponent cannot prove against a Mādhyamika some relevant tenet? This appears pretty irrelevant in the present connection, because the context does not present us any reason why the advocate of the Sāmkhya-view should be obliged to present any argument at all. After all, Candrakīrti wants to show that Buddhapālita's reasoning refutes the Sāmkhya-tenet and that this is the (only) correct way to achieve this goal. If Candrakīrti under those circumstances resorted to the idea that a Mādhyamika has the freedom to disclaim any possible reason which the Sāmkhya-supporter might adduce in favour of his thesis and therefore to stick to his own view, would the Sāmphyaproponent not possess the same right to direct the very remark against his opponent which Candrakīrti has made previously in the text, 
namely that if somebody is so "shameless" not to let himself be convinced by any argument, a debate is inappropriate and: na conmattakena sahāsmākam vivādah?

It is time to look for another interpretation of the pertinent textual passage. We had mentioned before (p. 119) that MacDonald envisaged the possibility that ayam in na/sa cāyam param prati might refer to a Mādhyamika, but rejects this supposition because "we are met with an untimely and strange defense of the Mādhyamika's procedure of proof, would have to accept that asya of the next sentence does not refer back to ayam of the previous, and are confronted overall with a logically unsatisfying sequence of statements".

For the time being we can neglect the remark relating to the non-identity of the reference of asya and ayam in different sentences. It seems at any rate to possess little weight, but we will revert to this point later. What about the claim that "we are met with an untimely and strange defense of the Mādhyamika's procedure of proof ... and are confronted overall with a logically unsatisfying sequence of statements" if we do not assume that ayam in na/sa cayyam param prati does not refer to an advocate of the Sāmkhya? Does not the following translation of the passage tasmād eṣa tāvan nyāyah ... $\bar{a} d h \bar{a} t u m$ iti embody a plausible interpretation?

Therefore, first, the norm [for any proof in a debate] is this that the other [interlocutor] himself has to furnish a means of proving the asserted proposition which is accepted by him. But this one (i.e. the Mādhyamika who acts according to the postulate that has been advocated in the preceding objection) employs against [the] other [interlocutor] (i.e. his opponent) only a means of proving the proposition asserted by himself in such a way that its essence is only an assertion [and not as something which is accepted by him] because [for him] indicators and examples are not possible [as entities which are acknowledged as existing by him]; therefore he brings only himself into inconsistency [with himself] because he accepts a thesis as something which lacks [appropriate] support and cannot instill conviction in other [persons, who do not by themselves believe his thesis, in particular his opponents].

A major advantage of the interpretation according to which ayam in sa cāyam param prati is employed in order to refer (in a general manner) 
to a(ny) person who follows the advice that had been formulated in the preceding objection is that it allows one to give a precise account of the import of hetudrștāntāsambhavāt pratijñ̄āmātrasāratayaiva kevalam svapratijñātārthasādhanam upādatte. First we can understand kevalam as a "scale-down"-particle which in a similar manner as "merely" can be employed to express that something occupies a relatively low degree on some (presupposed) scale of ranking. In this particular case kevalam possesses the constituent pratijñāmātrasāratayaiva ... svapratijñātārthasādhanam as its focus and is used to convey that a means of proving an asserted proposition which is such a means only in the form that is described as pratijñāmātrasāratay $\bar{a}$ occupies a low position with respect to a scale of convincing force. eva in pratijñammātrasāratayaiva can be taken as a contrastive particle that underscores a contrast with respect to sväbhyupagata- occurring in the compound of the preceding sentence.

Most important is, however, to give an account of the precise import of pratijñamātrasāra- and in particular of the sense of the metaphor em-

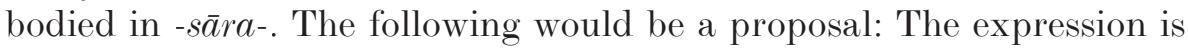
employed in order to refer to the circumstance that the Mãdhyamika following the recommendation of the objection would employ indicators and examples not as something which is acknowledged by himself, but merely as something which ensues from the opponent's thesis, which functions as their "essence" or "pith". The idea is the following: The Sāmkhya thesis that things originate from themselves implies that things exist (as that what they are). The suggestion that the Mādhyamika should formulate an argument of the form "A's do not originate from themselves, because A's exist (as what they are)" means that a reason is employed by him which he does not accept on his own account as true - because according to his own doctrine nothing exists on the level of final analysis - but which he has only derived as something ensuing from the opponent's thesis, and on that account one could say that the reason has a thesis as its "essence".

Unfortunately it is less clear, how the same idea can be related to the citation of examples. Perhaps the underlying thought is that the thesis that things originate from themselves is propounded by someone who accepts the existence of particulars (even on the level of final analysis) and accordingly even of the examples which the Mādhyamika mentions or might mention, so that one can say that the opponent's thesis indirectly, i.e. via the doctrine of the one who propounds it, entails the existence of the examples so that it can be metaphorically described as 
the "pith" or "essence" of the examples too. Otherwise, it is conceivable that the metaphor refers, strictly speaking, only to the reason and not to the examples.

At any rate, it is because the expression pratijñāmattrasāra- can be connected with a clear idea that we prefer the reading pratijñamātrasāratayaiva to svapratijñamātrasāratayaiva, the reading which has been adopted by MacDonald. The occurrence of $s v a$ - can be easily explained on the basis of the supposition that pratijñammatrasāratayaiva is original because the expression svapratijñātarrthasādhana that almost immediately follows could have plausibly caused the corruption. Nevertheless, it is worth noting that our interpretation is not essentially committed to the suggested reading. If one assumed svapratijñāmātrasāratayaiva as correct one could explain the metaphor in the following manner: Since the Mādhyamika cannot acknowledge indicators and examples as existing entities of his own accord, his exploitation of them for the purpose of the proof of his own assertion that things do not originate from themselves results merely from the circumstance that by his own thesis and in the context of proving it by reasons and examples he "provisionally" adopts the stance that particulars exist. Again there is a clear contrast with respect to the idea of acceptance of one's own accord, which is referred to the expression sväbhyupagata- in the compound in the preceding sentence. Why this embodies an inconsistent attitude which can be characterized by the words svātmānam evāyam kevalam visamvādayan should not be difficult to discern.

The interpretation of the subsequent sentence idam evāsya spastataram dūṣanạn yaduta svapratijñātārthasādhanāsāmarthyam iti kim atrānumānabādhodbhāvanaya prayojanam is mainly identical to the one given by MacDonald. It only deserves to be noticed that our interpretation of the preceding sentence opens the possibility to understand spastataraas a genuine comparative. Accordingly we would translate it not by "very clear" as MacDonald, but by "clearer". The import of the whole sentence is that in comparison with the "refutation" that relies on a canonical anumāna employing a "correct" thesis, "correct" inferential indicator and "correct" examples as it had been proposed in the objection formulated in LVP p. 18,5-9 and that leads merely to a self-inconsistency on the part of a Mādhyamika, the fact that the means of establishing the Sāmkhya-tenet are insufficient, i.e. that the proposition 
that things originate from themselves cannot be proven in a convincing manner, constitutes a clearer refutation of the Sāmkhya-theorem. There is no cogent need to assume that the Mādhyamika has actually brought forward an argument which proves not more than that the means of proving the relevant proposition are insufficient. The sentence merely implies that this insufficiency is a feature of the Sāṃhyatenet which shows the untenability of this view in a clearer manner and that the Mādhyamika would refute the Sāmkhya-theorem more clearly if he pointed out this fact than if he followed the advice of the objector of LVP p. 18,5-9. The circumstance that asya in idam evāsya does not have the same referent as ayam in sa cāyam param prati in the preceding sentence is quite irrelevant. The pragmatically decisive property of the use of demonstrative pronouns is that their reference can be found out by a potential hearer or reader with sufficient certainty and without requiring an unreasonable amount of effort, and in the present case the circumstance that asya in idam evāsya has to refer either to a Sāmkhyaproponent or to the tenet that things originate from themselves follows from the context with sufficient clarity. ${ }^{6}$ The above cited sentence can accordingly be translated as follows:

This [constitutes] a clearer refutation of him/it, namely that [the] means [by which the Sāmkhya-proponent could] prove the proposition asserted by himself are insufficient, and therefore [one must ask:] what [should be] the use of putting forward a refutation [of that proposition] by a [canonical] inference/proof here?

In the subsequent passage Candrakīrti acknowledges that the Mādhyamika might nevertheless need to present a demonstration of the faultiness of the Sāmkhya-proposition by a proof of his own accord.

6 For similar reasons it would be improper to suppose that all occurrences of para- in LVP p. 19,1ff. should have identical referents. In fact, parasmai in saivopapattih parasmā upadestavya refers in a general manner to everybody against whom a proponent intends to prove something. parena in yat parenaiva obviously relates to any proponent who as an opponent in a debate intends to offer a proof. Given that the referent of ayam in sa cayam param prati is identified as any Mādhyamika who follows the recommendation of the objection the referent of para- in param prati can be easily determined as anyone against whom this Mādhyamika intends to demonstrate that the Sāmkhya-tenet is false. Note that there is, strictly speaking, no necessity to assume that para- relates to a Sāmkhya-opponent; it can be related to any arbitrary interlocutor of the pertinent Mādhyamikaproponent. 
The answer is that Buddhapālita has fulfilled this demand. ${ }^{7}$ The subsequent passage of LVP p. 20,1-21,6 is obscure with respect to certain details. Nevertheless, it appears that the point which Candrakīrti wants to make is the following: Buddhapālita has by the expression tad in tadutpādavaiyarthyāt referred to the property of "existing in its own nature" (svātmanā vidyamāna-). There is an entailment between this property and the property of being such that a (second) origination is superfluous - or a property which involves an infinite regress. Accordingly one must assume the existence of an inseparable connection between the property of something's existing as what it is on the one hand and the property of not originating (again after that time). Though it must be admitted that Candrakirti's formulations do not express his point with absolute clarity one might reconstruct the gist of his considerations in the following way: From any proposition of the form "A originates from itself" it immediately follows that something which is identical with A and exists at some time "in its own nature" (i.e. as that what it is) originates at some subsequent time again. Accordingly A must exhibit the property of existing at some time "in its own nature" and originating again at some later time. But this latter property is "invariably connected" with the property of possessing a superfluous origination. In order to escape the danger of an infinite regress one has to assume that nothing possesses the latter property. Accordingly A cannot possess the property of existing at some time "in its own nature" and originating again at some later time and this implies (by modus tollendo tollens) that A does not originate from itself.

It seems that Candrakīrti's reason for attributing to Buddhapālita a refutation by an anumāna is due to the fact that he regards it as relying on some relation of indicator (hetu) and indicated property (sadhya) and accordingly on an inseparable connection between those properties, namely "existing in one's own nature" and "being such that a(ny later) origination is useless/absurd". ${ }^{8}$ Candrakīrti nowhere explicitly says why this way of refuting the counter-thesis by an anumana is preferable to the one which had been suggested in the objection of LVP p. 18,5-9. So we have no other alternative than to find out what might objectively distinguish this method of refutation from the rival one.

7 LVP p. 19,8: athāpy avaśyam svato 'numānavirodhadoṣa udbhāvan̄yah. so 'py udbhāvita evācāryabuddhapālitena ....

8 Cp. LVP p. 20,5-6: tatra svātmanā vidyamānasyety anena hetuparāmarśah. utpādavaiyarthyād ity anena sādhyadharmaparāmarśah. It would be more adequate to speak of a conceptual relation here. 
As far as one can see the most plausible account is the following: Buddhapālita's refutation by proof does not rely on categorical, but merely on conditional propositions. The decisive factor which leads the Mādhyamika who follows the recommendation proposed in the section of LVP p. 18,5-9 into self-inconsistency is that he uses an argument of the form "A is S, because A is H, like B". If a Mādhyamika says - in Bhāvaviveka's manner - "The inner Āyatanas do not originate from themselves, because the inner Āyatanas exist (as what they are), like the mind (caitanya)" or something similar, he employs a linguistic form which due to its "factivity" presupposes or entails propositions which cannot be regarded as (ultimately) true by the proponent himself. The most natural way to circumvent this problem is to substitute arguments of the form "A is $\mathrm{S}$, because $\mathrm{A}$ is $\mathrm{H}$, like B" by arguments of the form "A is $\mathrm{S}$, because if A were not $\mathrm{S}$, then A would be $\mathrm{H}$, and if A were $\mathrm{H}$, then A would be (I, J, K ... and therefore) S". The hypothetical form opens the possibility to get free from the wrong existential presuppositions, because the proper proof could be more explicitly formulated in the following manner: "because if there were an A which is not S, it would be $\mathrm{H}$, and if there were an A which is $\mathrm{H}$, it would be (I, J, K ... and therefore) S." The citation of examples does not present any serious problem because they can be viewed as a mere device to cause the opponent to recognize that he has no other choice than to acknowledge the truth of the pertinent conditionals, and the Mādhyamika does not necessarily become inconsistent if he "provisionally" accepts the presuppositions of his interlocutor in this manner.

It is true that all this does not yet remove the seemingly categorical form of the thesis itself. But even this problem can be solved if one recognizes that the pertinent proposition which the Mādhyamika has to prove contains a negation. It is merely required to give the correct account of the logical form of the thesis itself. Again, the most plausible solution is to maintain that the form of the thesis, although it has been represented above by "A is S" corresponds to a negated existential statement and would be more adequately rendered by the formulation "There is no A which is $\mathrm{S} *$ ". The explicit form of the entire proof would accordingly be the following: "There is no A which is $\mathrm{S}^{*}$, because if there were some A which is $\mathrm{S}^{*}$ it would be $\mathrm{H}$, and if there were some A which is $\mathrm{H}$, it would be (I, J, K ... and therefore) not $\mathrm{S}^{*}$." It must be probably admitted that the last mentioned proof-schema does not fit in the framework of the classical anumana-doctrine. But perhaps nothing else follows from this circumstance than that on the objective level 
Candrakīrti could possess excellent reasons to reject the postulates which have been advocated by Bhāvaviveka - or at least to reject postulates which Candrakīrti took Bhāvaviveka to propagate.

It turns out that the interpretation of the passage LVP p. 19,3-7 has major consequences for the understanding of a much larger textual segment of the Prasannapadā. It might not even be exaggerated to say that it possesses potential relevance for the understanding of fundamental features of Candrakīrti's philosophy and methodology. A prima facie minor detail of textual criticism thus attains an amount of significance which one would hardly expect at first glance. On the other hand, the preceding investigations highlight the fact that textual criticism becomes fruitful only if it is combined with most detailed textual interpretation. There are cases in which it is apposite to account for each individual word including the most minute particles.

It is easy to say that one should account for all details in textual interpretation, but it is much less easy to explain what exactly this means. MacDonald's paper on the Prasannapadā evokes the impression that the author's approach deserves to be clearly distinguished from much of common Indological practice, in particular much work which has been done in the field of Madhyamaka studies. Nevertheless, one can discern certain traces of "traditional" ways of working which are suited to hamper progress. One trait which can be detected even in "good philological tradition", but which impedes a more efficient employment of methodological tools, is a particular type of lack of selfreflection. This consists in a tendency to rely on intuitions at the expense of explicit and rigorous investigations on objective properties which an interpretation that one has proposed or wants to propose possess. One could express the point also by saying that though one puts the question as to what something means one fails to pose certain questions as regards the significance of something's meaning one thing or the other and, more specifically, what would follow if something - e.g. a particular textual passage - really meant what one believes it to mean.

Let us elucidate more precisely what this means. A general form of questions which have to be addressed within the framework of self-reflection in the context of text-interpretation is: "If (expression) E 
means P, which consequences would this have for F" or more explicitly: "If the producer (utterer/writer) of $\mathrm{E}$ should have meant by $\mathrm{E}$ that $\mathrm{P}$, which consequences would follow with respect to $\mathrm{F}$ ?" This general form possesses - among others - the following specification: "If E means P, what consequences would this have for the meaning = the relevance/ function of F?" or: "If the producer of $\mathrm{E}$ should have meant by $\mathrm{E}$ that $\mathrm{P}$, what would $\mathrm{F}$ mean $=$ which relevance or which function(s) would $\mathrm{F}$ possess?" Though there might be other alternatives to implement this question, implementations which pertain to instantiations of $\mathrm{F}$ consisting in expressions occurring in the same text - and particularly expressions which occur in the same textual segment - as E are specially significant.

There is no principal reason why the range of relevant expressions should be limited to some particular level, for example the level of sentences or the level of words. Accordingly one could relate the above formulated question to the totality of all meaning-constitutive expressions of the (con)text to which some expression $\mathrm{E}$ belongs, and since this pertains to all levels $\mathrm{E}$ itself and all its parts which are constitutive for its meaning are included in the range. With this we have obtained one possible explanation of what the phrase "to account for all details in textual interpretation" could mean even if it must be borne in mind that we do not have any assurance that this explanation is exhaustive. But we are in a position to substitute the vague dictum that one should account for all details by a much more precise maxim which says: "If one entertains the hypothesis that some expression E means (that) $\mathrm{P}$ - or: that the producer of $\mathrm{E}$ has meant by $\mathrm{E}$ that $\mathrm{P}$ - one should consider all expressions occurring in the same (con)text as $\mathbf{E}$, including all meaning-constitutive elements of $\mathrm{E}$, and ask which function could be ascribed to them if the hypothesis should be correct."

Now, this maxim can only represent an ideal, and it would be inappropriate to derive the postulate that an interpreter should fully comply with such a requirement in individual cases. Nevertheless, the ideal possesses relevance for practice inasmuch as one can reasonably demand that one puts hypotheses of interpretation to test by selecting a number of relevant expressions and investigating which function(s) they would be suited to perform if the hypotheses were correct, and in the first place of course, whether or not they could be assigned any intelligible function at all. In this manner one can with respect to the passage LVP p. 19,3-7 pose the question: "If ayam in sa/na cāyam referred to a Sāmkhya-proponent what function could be assigned to the sequence 
of sentences yo hi yam artham pratijānīte, tena svaniścayavad anyeșām niścayotpādanecchayā yayopapattyāsāv artho 'dhigatah saivopapattih parasmāy upadeștavyā. tasmād eșa tāvan nyāyo yat parenaiva svābhyupagatapratijñ̄atārthasādhanam upādeyam?" Given that the linguistic interpretation of this expression can be considered as sufficiently safe one can pose the further question: "If ayam in sa/na cāyam referred to a Sāmkhya-proponent what (pragmatic) function could the act of mentioning the principle that any opponent in a discussion must expound the basis by which he himself has recognized the truth of his own thesis possess?" As a matter of fact, it has turned out that it is not easy to ascribe any plausible function at all to the utterance of those sentences under the assumed hypothesis concerning the function of ayam because all the difficulties which affect the Sāmkhya-tenet do not specifically result from the circumstance that a Sāmkhya-proponent asserts this tenet (in the context of a debate). In contradistinction to this the significance of the pertinent remarks is immediately obvious under the alternative hypothesis that ayam refers to a Mādhyamika who follows the recommendation proposed in the preceding passage because the proposal of the objection entails that a Mādhyamika should prove his counter-thesis by a canonical proof.

Analogous questions can be raised with respect to individual constituents of the expression the interpretation of which is at stake. Given that one has decided to assign to some occurrence of eva some grammatical function like that of a quantifier in the sense of "only" or that of a "scaling-particle" or that which corresponds to contrastive stress in other languages one can investigate which pragmatic point can be assigned to the employment of that particle in this grammatical meaning, if the envisaged interpretation of the unit to which it belongs as a constitutive element should be correct. In this manner it has been proposed by us to assign to the occurrence of eva in pratijñ $\bar{a} s \bar{a}$ ratayaiva the role of highlighting a contrast with respect to sväbhyupagata- of the preceding sentence under the hypothesis that the sentence beginning with sa cayyam param prati refers to the procedure that had been proposed in the preceding objection.

It is important to be aware of the principal limitations of these types of consideration: They only demonstrate that whereas some function can be assigned to some element under the hypothesis of some interpretation no other possible function with at least the same degree of plausibility has been detected under the hypothesis of certain rival interpretations. This is of course not an absolute proof that alternative 
functions do not exist, and one can in principle always attack the presupposed basis of plausibility assignments. But these are limitations of a principle nature and do not pertain to individual interpretations in particular. It might be appropriate to point out this fact because there appears to be a propensity to question preferences of interpretation which are based on pragmatic considerations by reference to such theoretical possibilities. But here it must be retorted that this is an empty criticism because it treats limitations of principle as problems confronting particular interpretations. Merely pointing out theoretical possibilities can be a pointless enterprise, and in the field of Sanskrit studies at least it is still worthwhile to attempt to develop the faculty of discrimination between relevant and not relevant considerations of possibilities.

The aforementioned limitations do not diminish the central significance of the principle of the assignment of intelligible pragmatic functions to the totality of the members of sets of all expressions that are employed in some (con)text. Although it might not be always realistic to carry out investigations with respect to some totality and despite the fact that it is often difficult to detect possible functions that could be relevant, the principle plays a vital role inasmuch as it distinguishes good interpretations (of the pertinent type) in general that they provide a basis for assignments of intelligible roles to maximal sets of expressions occurring in the same (con)text as the interpretandum. It is, however, necessary to betake oneself to a deeper level of analysis if one desires to see in precisely what sense and why this holds true.

In his famous paper "Logic and Conversation" P. Grice has formulated a fundamental principle which reads

Make your conversational contribution such as is required, at the stage at which it occurs, by the accepted purpose or direction of the talk exchange in which you are engaged. ${ }^{9}$

This proposition has been labelled as the "Cooperative Principle". The wording reveals that the author envisaged in the first place oral communication. This is not essential, however, and the way in which this principle has been employed by Grice himself presupposes that it is equally valid for written communication. If the underlying idea of the principle is exploited in a specific manner, it attains relevance in the context of text-interpretation. Under the assumption that the postu-

9 Cp. P. Grice, Studies in the Ways of Words. Cambridge, Mass. 1989, p. 26. 
late which has been formulated by the Cooperative Principle has been complied with one can derive that a speaker or producer of a text employs means for the realization of his communicative goals which are suited for this purpose.

At first glance this could appear self-evident, if not trivial. Have we not always assumed that the author of a text uses appropriate words in order to express what he intends to say? This is true, but the impression that the point is only trivial should vanish as soon as we go a bit deeper into the matter. First of all, the idea entails some consequences with respect to the formal property of a certain type of argument-possibly the most important type - for interpretations of textual passages. It reveals that certain sorts of arguments are implicitly relative to hypotheses about (communicative) goals. It is precisely this feature which yields a criterion for the assessment of interpretations, and it is not difficult to see, how this functions: By hypothesizing a particular interpretation for some expression or textual segment a number of suppositions concerning (communicative) goals of the producer (author) follow, which function together with the pertinent expression or textual segment as the two relata which are assessable with respect to the adequacy of one to the other. That interpretations are prevented from assigning arbitrary goals to given expressions under all circumstances is ensured by some conventional import or linguistic meaning of the concerned expressions. But this by itself does not yet guarantee that assessments of adequacy between goals and means constitute an efficient tool for the evaluation of interpretations because one must expect that hypotheses about the (communicative) goals of some utterer or writer are derived under the hypothesis that the employed expressions are suitable means for whatever goals their producer might aspire to by their employment so that the whole enterprise could appear circular.

At this point it becomes crucial that compliance with any sort of cooperative principle leaves open a plurality of choices. In particular, fulfilment of the requirement as it has been laid down in the Cooperative Principle does not uniquely determine a particular choice of words even with respect to some specific communicative goal. Most important is, however, that adequacy of means to goals is a matter of degree. If we hypothesize a set of communicative goals on the basis of the hypothesis of mere adequacy of means to goal, we have not necessarily uniquely determined the only admissible set. Among the admissible sets some subset can be distinguished by the fact that the degree of adequacy between means and goals is significantly higher with regard to 
that subset than with respect to other subsets. Since different hypotheses concerning goals can ensue from different interpretations it can occur and in fact occurs sometimes that an employment of certain expressions can be assessed as a more adequate means with respect to some set of goals ensuing from one interpretation than with respect to alternative sets of goals ensuing from rival interpretations. It is precisely in such situations in which a principle attains importance which could be named "the principle of optimal linguistic performance" - or if it were specifically related to written communication "the principle of optimal text".

The principle itself is quite easy to understand. It says that if there are different interpretations of some identical interpretandum such that some (set of) interpretation(s) entails the existence of goals on the part of the producer of the interpretandum which are better achieved by (the production of) the interpretandum (in some given context) than other goals entailed by the alternative interpretations, then the former interpretation is - ceteris paribus or by default - preferable in comparison with the rival ones. Accordingly, if some interpretation implies that some interpretandum harmonizes with the entailed (communicative) goals to an optimal degree there is no other interpretation which could be preferred on the basis of the same criterion. Since this requirement is only fulfilled if for every meaning-constitutive element of the interpretandum - given that there are any - an intelligible function exists, the principle of optimal linguistic performance entails that all questions pertaining to the function of any such element are relevant for assessments of interpretations. This has some parallel in the third Gricean maxim of the category "Manner": "Be brief (avoid unnecessary prolixity)." It is equally quite easy to discern the rationale behind the maxim of preference on account of optimal linguistic performance: It ensues from the formal principle that anyone intending the realization of some goal intends to realize it by the best possible means. It is because of the formal nature of this theorem that it possesses good prospects to be successfully applicable with regard to alien cultures. ${ }^{10}$

10 Surprisingly, a number of persons apparently did not even grasp these relatively simple facts when the principle was presented to them and till the present day I am uncertain whether or not this indicates quite general deficiencies in the humanities at present. Be that as it may, another observation would surely indicate a methodologically backwardness at least in the Oriental disciplines, if it should be correct: In P. Grice's framework the conversational maxims are employed in order to account for deviances between what can be termed as literal or linguistic 
In the following section I will confine myself to point out some - presumably not trivial - aspects pertaining to the application of the principle of optimal linguistic performance.

A) The principle of optimal linguistic performance is not the only principle relevant for the assessments of interpretations related to the Cooperative Principle. It has been made plain that this principle is of a relational nature and pertains to the relation between some item that is to be interpreted and intended goals the existence of which follows from the (hypothetical) supposition of the correctness of some interpretation. In contradistinction to the interpretandum which is treated as given - if questions of textual criticism pertaining to the correct wording are considered as (if they were) settled in the pertinent context of investigation - the other relatum, the intended goals, possesses merely a hypothetical status. For precisely this reason hypotheses concerning interpretations have also to be assessed by another criterion, namely the probability of the existence of the goals or of the corresponding intentions on the part of the producer of the item to be interpreted. Since in all problematic (and interesting) cases of interpretation a plurality of alternative hypothetical communicative goals or intentions has to be taken into account, the interpreter is confronted with the task of comparing - and possibly ranking - the alternatives under the aspect of their probability. This in its turn engenders the problem of finding criteria for the assignment of probabilities with respect to the different (communicative) goals and intentions that are entailed by the alternative hypotheses of interpretation.

Now, there are several means of restricting arbitrariness in this regard, but possibly the most important criterion is indirectly related to the Cooperative Principle. It becomes effective in all types of communication in which a plurality of communicative acts occur in sequence and are thematically related to each other, but mostly in texts. In such

or "compositional" meanings of linguistic expressions and what is conveyed by their employment in communicative acts. This shows that one has to be aware of the fact that that which appears to be the content of some utterance is not always directly related to semantic features of linguistic expressions and this in its turn is relevant for semantic studies, in particular for projects, which in the Germanspeaking tradition are often - quite misleadingly - called "Begriffsforschung". The methodological deficiency results from the circumstance that the facts which have been highlighted by Grice's theory are simply ignored. 
cases it is common that the utterance or writing of units of the sentence-level is designed to contribute together with other units of the same level to some common purpose or set of purposes. This makes it meaningful to assess individual units under the aspect of the contribution which they are suited to make to some superordinate topic or goal, i.e. under the aspect of relevance. There is a link to Grice's maxim of the category "Relation" which reads "Be relevant".

The consideration that it is difficult to attribute a plausible function to the utterance of the sentences stating the requirement that somebody who proves something against somebody else must exhibit the basis by which he himself has recognized the truth of his thesis if the sentence beginning with sa cāyam param prati were taken to relate to a Sāmkhyaproponent whereas the point would be immediately obvious if that sentence related to a Mādhyamika following the recommendation of the objection exemplifies the sort of argument that concerns relevance. It shows that arguments of pragmatic function must not necessarily pertain to the unit to be interpreted but can refer to larger units to which the interpretandum belongs. Accordingly, we must distinguish between two principles of optimality: One that concerns the relation of adequateness of linguistic means to (hypothetical) goals and intentions and one that concerns the relation between the existence of goals or intentions to other, in particular more global, (communicative) purposes. Since both principles are related it might be useful to refer to them by a common term, say "principle of optimal communicative performance", and to the two varieties by the expressions "principle of optimal contextual relevance" and "principle of optimal linguistic performance".

Now the questions might be posed, first, whether and if then why those principles are valid and, secondly, whether and to what extent they are significant. As regards the first problem we will return to it later and confine ourselves here to saying that the mere fact that they can be brought into connection with the Cooperative Principle is not a sufficient basis for their validity. Concerning the second question it deserves to be remarked that the difference between the two principles is crucial in connection with the distinction between different categories of interpretation. This holds good in particular for the distinctions between "radical interpretation" - in the sense in which the term is widely used in the tradition of W.V.O. Quine and D. Davidson - and "philological interpretation" as well as with regard to the difference between learning a first language and interpreting utterances of a language which one 
already knows. - I advocate the thesis that in interpretations of the latter types both principles are relevant whereas in interpretations of the former types only the "external" principle of contextual relevance comes into play. ${ }^{11}$

As far as philological interpretation is concerned, the difference between the maxims of optimal contextual relevance and optimal linguistic performance attains relevance on account of possible conflicts between verdicts which are induced by the principles; this means it can occur that one interpretation appears preferable to another on account of the criterion of optimal adequacy of employed linguistic means to intended goals and simultaneously less preferable on the basis of the criterion of plausibility of goals under the aspect of relevance to context. The question as to how and on which theoretical basis such conflicts can be dealt with will not be pursued further here; it is at any rate better to treat this problem in a broader perspective in which also other principles generating similar conflicts are taken into consideration. Despite the fact that optimality principles do not exhaust everything that is relevant for assessments of interpretations they possess utmost significance. Without them the entire enterprise of philological interpretation would become absolutely useless. The circumstance that the principles of contextual relevance and of linguistic adequacy, which have been implicitly acknowledged in the philological tradition, seem to be more and more disregarded in recent times is the main reason that the right of existence of Sanskrit philology appears endangered to me at present. In some regards optimality-principles are the opposite of trivial.

B) As the principles of optimal contextual relevance and optimal linguistic performance refer to the dimension of linguistic behaviour their application requires a particular kind of precaution. People determine their own behaviour primarily by how they view their behaviour, and inasmuch as they aspire to behave in some way or the other not objective qualities of virtual ways of behaving are decisive but subjective judgments about them. Accordingly if a subject attempts to behave optimally in some respect his/her actual way of behaving is not determined by the fact that it is optimal but by the fact that he/she believes

11 "Contextual relevance" should be taken in a sufficiently broad sense so that it encompasses relations between utterances and their non-linguistic (situational) context. I do, by the way, not intend to suggest that the terms "radical interpretation" and "interpreting a language" are equivalent. 
that it is. Linguistic behaviour is no exception. That somebody's linguistic performance exhibits excessive prolixity because he underestimates the knowledge of his audience or that a speaker or writer overestimates the competence of his addressees and expresses himself too concisely or too theoretically are well known phenomena. In the context of interpretations of utterances or texts this fact must be taken into consideration, but it is not detrimental to the whole enterprise.

First there is the possibility to detect relevant misconceptions on the part of the producer of the utterance and to find out how he (probably) had viewed his own speech-behaviour. Moreover, in many instances the existence of such misconceptions can be ruled out with a sufficient degree of certainty. If this is not possible, one can try to base judgments on a sufficiently large number of features of behaviour so that the possibility that the interpreter's verdicts are crucially affected by the existence of undetected misapprehensions is low. Nevertheless, generally speaking the possibility of deviances between objective and subjective assessments of speech-behaviour endangers considerations that rely on the principle of optimal contextual relevance to a higher degree than those that are based on the principle of optimal linguistic performance. It seems that the probability that an utterer grossly misjudges the adequacy of his linguistic means to the immediate (communicative) goals that he intends to realize by them is significantly lower than the probability of major misjudgements concerning the contextual relevance of his/her remarks, at least as long as one hypothesizes that the producer of the unit to be interpreted is a competent speaker of the pertinent language. Therefore it is not unreasonable to attribute to considerations pertaining to the adequacy of linguistic formulations more weight for preferability-assessments between interpretations than to considerations concerning relevance, at least by default, i.e. as long as no particular reasons recommend a different view. The problem of divergences between objective properties of behaviour and subjective ascriptions of properties on the part of some behaving subject must be clearly distinguished from the problem of possible misjudgements about objective qualities of linguistic behaviour on the part of the interpreter(s). ${ }^{12}$

12 In the present context of discussion we simply assume, for the sake of argument, that those who intend to assess different hypotheses of interpretation possess correct views about pertinent features of pertinent instances of linguistic behaviour. In fact this assumption cannot be taken for granted especially if linguistic products of remote times and alien cultures are at stake. 
C) The validity of optimality-principles of interpretation does not presuppose that linguistic behaviour is in fact optimal. It could appear tempting to object that even if misconceptions about objective properties of virtual linguistic behaviour do not exist and given that some speaker or writer aspires to achieve his immediate or global communicative goals in some optimal possible manner - note in passing that there is no need to assume that there is always exactly one optimal linguistic behaviour - the actual behaviour of some utterer might exhibit deficiencies because certain factors - like lack of time to find a best possible formulation or lack of linguistic or communicative skills - prevented him from fully achieving his aspirations. Must one not conclude that the optimality-principles which have been propagated above rest on unrealistic idealisations? I claim that this objection is fundamentally mistaken. It cannot be expected $a$ priori that a criminal will create a great number of independent clues which indicate that he is the one who committed the crime. Nevertheless, if a multitude of pieces of circumstantial evidence are detected which support the same conclusion, it will be taken as a basis for an accusation and possibly a condemnation. It might occur that certain pieces of evidence fit together "too well" and that this must be taken as indicating an attempt to lay a wrong track. Similarly the circumstance that some formulation fits some possible thought or train of thought extremely well might indicate later manipulations of a text. But this does not affect the validity of the concerned principle. In fact, optimality-principles for the assessment of interpretations rely on the same ground as the principle of "cumulative evidence". A great amount of independent evidence for the same conclusion constitute a fact which cannot be easily explained by being due to mere coincidence. Similarly, as long as standards of adequacy are relatively low the $a$ priori probability that any arbitrary object meets the criterion is relatively high. If, however, the standard is high, the a priory chances of fulfilling the demand are low and therefore the fact that an object satisfies the criterion becomes significant. Accordingly, if some hypothesis of interpretation conforms to the principles of contextual or linguistic optimality, it immediately follows only that the hypothesis is significant, not that it must be correct. But significance is related to correctness in this case: As long as no particular reasons support a contrary conclusion the fact that the hypothesis is significant can be most plausibly explained by the assumption that it is correct. Consequently, in the context of linguistic interpretation optimalityprinciples are essentially default-principles. As long as no contrary evi- 
dence exists, the conclusion from satisfaction of the optimality-principles to correctness of an interpretation is valid.

To be sure, validity does not entail truth, and this holds good equally in the present context: The circumstance that no contrary evidence exists can be due to the circumstance that the producer of some linguistic object has objectively not produced sufficient evidence for a determination of his communicative goals. Parallel to the above presented elucidation of the notion of validity with respect to optimalityprinciples, we can formulate the following inference-maxim: As long as the existence of contrary evidence $i$ s not known one is justified to derive the correctness of an interpretation from the fact that it satisfies the optimality-principles. Being justified does not entail being safe. Apart from the possibility that producers of linguistic objects might not create sufficient indicators that make unique determinations of their communicative intentions (at least in principle) possible the fact that, even if contrary evidence is not known it might nevertheless exist, possesses obvious relevance here.

D) A methodologically reflected exploitation of the optimality-principles is of utmost importance. Texts which are concisely formulated, like for example the early sutra-texts, cannot be treated in a methodologically impeccable way, if considerations pertaining to (degrees of) perfection of linguistic behaviour are not brought into play. In this connection the principle of optimality of linguistic performance possesses special importance because it opens the possibility to critically assess the statements made by the indigenous commentators. In the long run, it does not suffice, however, to rely on intuitions in this regard. Although our philological tradition possesses quite a long history our practice still resembles in some respects the archaic procedures of ordeals: We give verdicts about interpretation without any critical reflection on their validity. Even if it should turn out that the criteria we are actually using can be justified to some extent, it is in the end unacceptable to merely rely on the hope or the feeling that our procedures happen to be correct. Apart from this, even if the "ordeals" which we employ at present in philology should not do too much injustice, we have no reason to abstain from actively looking for alternative methods for grounding our assessments. In particular, the prevalent passive attitude of testing hypotheses of interpretation on the background of an undifferentiated feeling of more or less adequacy can be substituted by an active stance which consists in systematically detecting and investigating objective features that some hypothesis of interpretation entails. 
With regard to the dimension of optimality of linguistic behaviour it is possible to search as many facts as possible in order to examine whether they together support the conclusion that the producer of the unit to be interpreted exhibited an optimally adequate way of (linguistic) behaviour. Even a policeman who investigates a case cannot content himself with some subjective feelings about culpability and it is required that he should not rely on considerations about possible motives of the crime alone but should actively look for independent evidence of different kinds and attempt to continuously enlarge the number of detected evidence. Here the fact that it might occur that for objective reasons not much evidence can be found would never be acknowledged as an excuse, and no judge would be allowed to lower the standards of explicit evidence on this account. The situation is the same in the field of philological interpretation. Only systematic search for evidence can provide a basis on which assessments of interpretations become transparent. If the efficiency of methods of interpretation were enhanced in this way, it would be indeed important. But something else is probably much more important at present: Explicit reflections on validity and their foundation, as they have been presented above, make transparent the extent to which safe knowledge concerning interpretations is possible; they reveal the limitations inherent in particular types of considerations and argumentations. Therefore they furnish effective weapons against charlatanism and diminish the danger that its representatives succeed in deceiving others provided that they have an effect on the standards of acceptability in a scientific community. As far as Indology at present is concerned, I fear that it is dangerously naïve to believe that those tools are not needed. 